\title{
Las exenciones fiscales en la Hacienda municipal
}

\author{
por \\ MANUEL PALOMAR LLOVET \\ $Y$ \\ ALBERTO DE ROVIRA MOLA
}

\author{
Abogados del Iltre. Colegio de Barcelona \\ Oficiales cualificados del Excmo. Ayuntamiento de Barcelona
}

SUMARIo: I. La generalidad en la obligación tributaria y las exenciones fiscales. Su reflejo en la Ley de Régimen local.-II. Distinción entre la exención fiscal $y$ otras instituciones afines. A) Exención fiscal y no sujeción impositiva. B) Exención fiscal e inmunidad impositiva. C) Exención fiscal y remisión impositiva.-III. Naturaleza y alcance del arí. 719, a), de la Ley de Régimen local.-IV. Exenciones concretas en materia de Hacienda municipal. A) Exenciones reconocidas expresamente en la Ley de Régimen local y otros textos complementarios. B) Examen específico de las exenciones habitualmente invocadas. 1. Exenciones paccionadas. 2. Exenciones a favor de la Iglesia. 3. Exenciones a favor del Estado. 4. Exenciones a favor de F.E.T. y de las J.O.N.S. y Delegación Nacional de Sindicatos. 5. Exenciones a favor de «Ayuda americana». 6. Exenciones a favor de las industrias de interés nacional. 7. Exenciones a favor de viviendas. 8. Exenciones a favor de entidades benéficas. 9. Exenciones a favor de Mutualidades. 10. Exenciones a favor de Cooperativas y Economatos laborales. 11. Exenciones a favor de las Cajas de Ahorro. 12. Exenciones a favor de la C. A. M. P. S. A. 13. Exenciones a favor de la Compañía Telefónica Nacional de España. 14. Exenciones a favor de las Empresas de transportes públicos.-V. Conclusión.

Al escribir el presente trabajo no hemos pretendido, ni mucho menos, agotar el tema que le sirve de título; nuestro propósito ha sido únicamente el de destacar la necesidad de una regulación más clara y eficaz de las exenciones fiscales locales. toda 
vez que si los preceptos básicos sobre la materia-contenidos en la Ley de Régimen local y en el Reglamento de Haciendas locales-son lo suficientemente claros para no ofrecer dificultad en orden a la aplicación de las exenciones a los casos concretos, no puede decirse otro tanto de las referencias que a este tema hace el resto de nuestro ordenamiento jurídico, las cuales vienen constituídas por un cúmulo de disposiciones de variado rango legislativo, la mayoria de naturaleza meramente administrativa, que a veces contrarían o desconocen aquellos preceptos básicos, introduciendo la confusión consiguiente según se trasluce de las vacilaciones en que incurren la Administración y aun los Tribunales de Justicia al dictar sus resoluciones sobre la materia.

\section{LA GENERALIDAD EN LA OBLIGACION TRIBUTARIA} $Y$ LAS EXENCIONES FISCALES. SU REFLEJO EN LA LEY DE REGIMEN LOCAL

Por sabido, no hace falta insistir en el carácter general que, en principio, tiene la obligación de contribuir, y que deriva de la igualdad de los ciudadanos ante la Ley y de su deber de participar proporcionalmente a sus medios en el levantamiento ce las cargas públicas, según la justicia distributiva exige, lo cual viene claramente expresado en los textos constitucionales de la mayoria de los Estados. Así, entre nosotros, el Fuero de los Españoles, de 17 de julio de 1945, declara que los españoles contribuirán al sostenimiento de las cargas públicas según su capacidad económica..., y en los «Principios del Movimiento Nacional», de 17 de mayo de 1958, se lee también que todos los espanoles tienen derecho... a una equitativa distribución de la renta nacional $y$ de las cargas fiscales...

La obligación de tributar es, pues, la regla general; pero, como vulgarmente se dice, no hay regla sin excepción, y en este casc ia excepción viene constituía por las ilamadas exenciones fiscales que, como su nombre indica, eximen de satisfacer el tri- 
buto. Como dice C. Albiñana (1), «cuando en una situación-base de imposición se dan, además de los hechos imponibles o presupuestos integrantes de aquélla, uno o más requisitos exigidos por la Ley para el disfrute de un régimen de excepción en cuanto a la prestación tributaria correspondiente, se está ante una exención del impuesto».

El hecho o acto exento se subsume o encaja, desde luego, en la descripción legal en que se configura la hipótesis de hecho de la norma tributaria; es, pues, un hecho o acto imponible, pero no resulta, en definitiva, gravado, y ello en virtud de una norma de carácter especial (que debiera estar siempre prevista en la propia disposición reguladora de la exacción), la cual, por razones extratributarias (de política económica, sociales, culturales, religiosas, etc.), excluye al hecho $o$ acto exento de la consecuencia juridica prevista con carácter general en la norma tributaria para los supuestos que califica como imponibles.

El principio jurídico de la generalidad de la imposición fiscal no queda desconocido por la existencia de exenciones, siempre que éstas, cualquiera que sea su naturaleza y la intensidad de su matiz subjetivo, respondan a criterios impersonales, ajenos, si se quiere, a las exigencias lógicas de la estructura legal del tributo, pero inspiradas mediata o inmediatamente en motivos de interés general.

Si nos fijamos en el carácter de los requisitos que las leyes exigen para eximir de imposición a determinadas situaciones, típicas desde el punto de vista tributario, observaremos que algunos de ellos se refieren al sujeto pasivo de la exacción (a su condición, naturaleza, cualidades, etc.), mientras que otros atañen a los elementos materiales o de hecho de aquellas situaciones 0 , más sencillamente, al objeto imponible (bienes, actividades, beneficios). De ahí la distinción que comúnmente hacen los autores entre exenciones subjetivas y exenciones objetivas. El concepto de exención subjetiva-expresa GIANNINI (2) con su habitual

(1) «Exención de impuestos», en Nueva Enciclopedia Jurídica, tomo IX. Barcelona, Seix, 1958, pág. 233.

(2) Instituciones de Derecho tributario. Traducción y estudio preliminar, por Fernando SaINZ dE BUJanda. Madrid, 1957, págs. 110-111. 
maestria, en frase en la que no sólo dilucida la apuntada distinción, sino la naturaleza jurídica y aun el fundamento de las exenciones-se da tan sólo en los casos en que la Ley, mediante una disposición de Derecho singular, declara no obligada al pago del impuesto a una persona o a una categoría de personas que, conforme a las disposiciones más generales de la propia Ley, quedarian comprendidas entre los sujetos pasivos, y no en los casos en que, por el modo de estar descrito y circunscrito en la Ley el presupuesto del tributo, aquella persona o aquel grupo de personas no resultan incluídos entre los sujetos pasivos del impuesto. En cambio-según el mismo tratadista (3)-, el concepto de exención objetiva se produce tan sólo en los casos en que la Ley declara no sujeto al impuesto a un determinado objeto por razones extrañas a la normal estructura que el ordenamiento legal imprime al tributo, y ello con el fin de sustraer a la carga fiscal y, por tanto, de facilitar el desarrollo de una cierta actividad económica que en un determinado momento se estima conveniente favorecer en defensa del interés general.

Ahora bien, si para ahondar más en la cuestión descendemos del campo de la dogmática jurídica al examen de la Ley positiva $\mathrm{y}$, concretamente, a los preceptos que regulan las exenciones tributarias en nuestro régimen local, descubrimos que exenciones subjetivas puras, es decir, determinadas solamente por requisitos exigidos al sujeto pasivo del tributo, no existen realmente en la Hacienda municipal española. Las que podemos llamar exenciones subjetivas, por referirse algunos de sus requisitos constitutivos a la naturaleza o cualidades del sujeto pasivo tributario, vienen integradas también por otros requisitos que afectan a los elementos de hecho de la base de la exacción, es decir, a su objeto (véanse a este respecto y como ejemplo, las exenciones configuradas en los arts. 438, 439,468,c), d) y $e$ ); $472, b), c), d)$ y $e) ; 491$, párr. $3 ; 498, d) ; 520$, párr. $1, c), d), g$ ), h) e i), y párr. 2, etc., de la Ley de Régimen local).

La única exención íntegramente subjetiva que cabría citar como incluída en la Ley de Régimen local es la que establece su

(3) Ob. cit., págs. 156-157. 
artículo 565 respecto de la «prestación personal» a favor de ciertas caregorías c̀e persoras en atención a si edad, estado de saiuã, prof́esión, etc. Ello es natural si se considera que, salvo esta prestación personal (de raturaleza sui generis, a pesar de venir incluída en la imposición municipal por el art. 477, $\tilde{x}$ ) de la Ley ce Eégimen locai), las exacciones municipales no son tributos personales, es cecip, no apoyan si objeto en la existencia de las personas como tales, sino en las actividades de contenido económico que realizan, en los bienes que poseen, en los beneficios que disfrutan, etc. En consecuencia, las motivaciones de interés general en que tcāas las exenciones (incluso las subjetivas y aunque ello parezca paradójico), deben, para responỏer a las exigencias de la justicia distributiva, fundamentarse, han de referirse a ciertas conciciones de carácter objetivo (el fin al que están asignados los bienes o los beneficios, el destino de la actividad, etc.), de modo que las exenciones sólo beneficien a las personas en tanto no se aparten de aquellas causas objetivadas. Oura cosa sería convertir las exenciones, justificables por razones de interés general, en inmunidad fiscal o arbitraria acepción de persona. Según la Ley de Régimen local, ni siquiera la Iglesia y el Estado, las dos únicas cociedades perfectas en su respectiva esfera de actividad, están exentas per se de satisfacer los tributos municipales y provinciales; sí lo están determinadas propiedades y actividades cie aquellos sujetos (v. arts. 439, 468, $472,498,520$, etc.) por razones extrafíscales, pero que no dejan de mirar y de redundar a la consecución del bien común.

En nuestro régimen local existen, pues, exenciones objetivas, configuradas exclusivamente por requisitos que afectan al objeto tributario, y exenciones subjetivas, determinadas por la concurrencia de requisitos que se refieren al sujeto y de otros que atañen a los elementos de hecho de la situación-base de imposición. La exención subjetiva pura no está reconocida en nuestra Ley. Por eso nos extraña el carácter marcadamente subjetivo con que en la práctica se postulan, y a veces se consiguen, las exenciones en nuestra Hacienda local, subrayando asi su indebida condición de privilegios mas que de justificadas excepciones a una obligación general de contribuir. 
En la legislación de régimen local el principio de la generalidad en el levantamiento de las cargas públicas y la configuración de la exención como una excepción a ese principio vienen expresados en términos enérgicos y con una técnica loable. En efecto, la Ley de Régimen local recuerda que la obligación de contribuir es de carácter general y que la exención, como excepción a la norma general, sólo es válida en cuanto esté reconocida en la propia Ley, en los dos momentos fundamentales en que se manifiesta la potestad impositiva de las Corporaciones locales: el de la imposición y ordenación de las exacciones, y el de la aplicación y efectividad da las mismas.

En cuanto al primer momento, el artículo 719 de la Ley de Régimen local dispone que «las Corporaciones locales, al acordar la imposición y ordenación de las exacciones, deberán tener inexcusablemente en cuenta: a) que la obligación de contribuir es siempre general en los límites de esta Ley y, en consecuencia, ni aquellas Corporaciones ni el Gobierno podrán declarar otras exenciones que las concretamente previstas y autorizadas en ella, debiendo tenerse por expresamente derogada toda otra exención actualmente en vigor, aunque se funde en razones de equidad, analogía o equivalencia, o en especial consideración de clase o fuero» (4), y en cuanto al segundo momento de la aplicación y efectividad, el artículo 659, párrafo 1, de la misma Ley establece que «con las excepciones previstas en esta Ley, en los casos y en ia forma que en ella se determinan, se prohibe a las Entidades locales enajenar o hipotecar sus derechos o propiedades y la con-

(4) Los restantes apartados del artículo 719 son del tenor siguiente:

«b) Que cuando las leyes otorguen exenciones a condición de reciprocidad internacional, las Diputaciones provinciales y los Ayuntamientos habrán de aplicarlas en su caso, no zudiendo considerarlas anuladas por falta de ella sin previa deciaración del Gobierno.

»c) Que la sola identidad del objeto, de la base o del contribuyente, y aun la de todos los dichos elementos de dos o más exacciones municipales o crovinciales, ro invalidan ringuna de éstas, siempre que los conceptos àe imposición sean diferentes, y

ग) Que salvo lo especialmento dispuesto en esta Ley en mareria de conciertos, aportaciones o auxilios, será nulo todo pacto, contrato o sistema que acuerden las Corporaciones lccales y que tengan por objeto la obligacion de contribuir, la forma o la cuantía de las exacciones.» 
cesión de exenciones, perdones, rebajas, moratorias o aplazamientos para el pago de los recursos provinciales o municipales o de los créditos, por cualquier concepto, que tuviesen liquidados a su favor» (5).

La Ley de Régimen local, en otros preceptos y con referencia a determinadas exacciones, hace hincapié en la prohibición de que los Ayuntamientos, por Ordenanza o acuerdo especial, reconozcan exenciones $o$ reducciones no previstas taxativamente en su articulado (asi, por ejemplo, en el art. 523, relativo al arbitrio sobre incremento de valor de los terrenos).

El citado artículo 719, a), de la Ley de Régimen local constituye la piedra angular de nuestro trabajo, pues de la determinación de su sentido y alcance depende, en buena parte, la solución de la problemática relativa a las exenciones tributarias en la $\mathrm{Ha}$ cienda municipal. Pero antes de adentrarnos en su estudio, conviene establecer ciertas distinciones que nos ayuden a comprender el concepto de exención fiscal, diferenciándolo del de otras figuras con las que a veces nuestra legislación la confunde.

Debemos también significar que dentro del concepto de exenciones se incluyen (y asi lo haremos nosotros) lo mismo las parciales (reducciones o bonificaciones) que las totales; las perpetuas (o, mejor, de duración indefinida) que las temporales.

(5) Estos preceptos no son nuevos en nuestra legislación. Por lo que se refiere al actual artículo 719 , a), de la Ley de Régimen local, está inspirado en el artículo 319 del Estatuto municipal de 8 de marzo de 1924-el cual, a su vez, lo tomó del artículo $4 .^{\circ}$ del proyecto de González BESADA, de 16 de julio de 1918-, pasando a través del artículo 268, a), del Decreto de 25 de enero de 1946, sobre ordenación provisional de las Haciendas locales, y del 693, a), del texto articulado de la Ley de Régimen local, de 16 de diciembre de 1950. Y el artículo 659, que es el 634 de ese texto articulado de 1950, está calcado de la Ley de Administración y Contabilidad de la Hacienda pública, de 1 de julio de 1911, cuyo artículo 5.9 dispone que «no se concederán exenciones, perdones, rebajas ni moratorias para el pago de las contribuciones e impuestos públicos, ni de los débitos al Tesoro, sino en los casos y en la forma que en las leyes se hubiere determinado». 


\section{DISTINCION ENTRE LA EXENCION FISCAL Y OTRAS INSTITUCIONES AFINES}

\section{A) EXENCIÓN FISCAL Y NO SUJECIÓN IMPOSITIVA.}

Hemos visto que el hecho o acto exento se subsume (encaja) en la descripción legal en que se configura la hipótesis de hecho de la norma tributaria y que es un hecho o acto imponible, aunque no resulte, en definitiva, gravado, en virtud de una norma de carácter especial que, por razones extratributarias, excluye al hecho o acto exento de la consecuencia jurídica prevista con carácter general en la norma tributaria. Por el contrario, el acto no sujeto no encaja en la descripción que hace la norma tributaria en la hipótesis de hecho; cae fuera de la figura fiscal y queda, por tanto, excluído, no de la consecuencia jurídica de la norma, como ocurre en el acto exento, sino de su hipótesis de hecho, como supuesto ajeno y extraño al ámbito de aplicación de la exacción.

El Tribunal Supremo, en sentencia de 10 de marzo de 1956, dice sobre este punto que «la exención es un privilegio contrá derecho común por razón del tiempo o de la causa, y sólo puede producirse precisamente cuando hay sujeción al tributo, constituyéndose en una mera suspensión de la efectividad de él, lo cual es cosa distinta a la no sujeción al impuesto, que es la que conduce a la exclusión del mismo cuando no se da en cada caso la razón que lo motiva».

Los casos de no sujeción no han de ser mencionados por la norma legal si no es a modo de aclaración o interpretación, en un intento de mejor delimitar por vía negativa la figura fiscal; cuando esto sucede, la Ley da lugar a veces, por imprecisión terminológica, a que se confundan las exenciones con los actos no sujetos. Este es, por ejemplo, el caso del artículo 497, párrafo 1, de la Ley de Régimen local (reiterado en el art. 69, párrafo 2, del Reglamento de Haciendas locales), el cual, con relación al arbitrio scbre casinos y círculos de recrec, establece oue «quedan excepsinodas las sociedades que tengan exclusiva:aexis $i$ in fin social, educativo o benéfico»; es evidente que este 
supuesto, más que una exención, constituye una descripción delimitadora de la figura fiscal por vía negativa o de exclusión, toda vez que si una sociedad tiene exclusivamente un fin social, educativo o benéfico ya no es un casino o círculo de recreo. Lo mismo puede decirse de los casos a que se refieren los artículos 548, párrafo 1, y 565 de la Ley de Régimen local, relativos, respectivamente, al arbitrio sobre carnes, volatería y caza menor y a la prestación personal y de transportes. En cambio, en el supuesto del artículo 184, párrafo 4, de la Ley sobre Régimen del Suelo y Ordenación urbana, de 12 de mayo de 1956, que dispone que no estarán sujetos al arbitrio sobre ordenación urbanística los jardines de propiedad particular cuyas plantaciones respondan a un trazado y ordenación adecuados, nos parece que se trata de una verdadera exención, a detallar en la correspondiente Ordenanza fiscal.

\section{B) EXENCIÓN FISCAL E INMUNIDAD IMPOSTTIVA.}

Como ya hemos señalado, en todos los ordenamientos jurídicos $\mathrm{y}$, especialmente, en los preceptos de rango constitucional o superlegal, se establecen como postulados la igualdad ante la Ley y la generalidad en la distribución de las cargas públicas. A ellos se opondría la inmunidad, o sea, la exceptuación fiscal basada o fundamentada en un privilegio personal y estrictamente subjetivo. No debe, por tanto, existir confusión entre las verdaderas exenciones, que exigen la concurrencia de requisitos subjetivos y objetivos, y la inmunidad fiscal, que obedece a circunstancias de índole arbitraria o a prejuicios de clase.

La inmunidad - explica BIELSA (6)-es una cualidad sustancial incompatible con la obligatoriedad de la disposición común de que se trate. La inmunidad resulta o de la naturaleza de las cosas o del Derecho fundamental. La exención, en cambio-agrega-, implica la exclusión parcial en la aplicación de un régi-

(6) Estudios de Derecho püblico, tomo II, Derecho fiscal. Buenos Aires, 1951, págs. 108-109. 
men general y ha de ser establecida expresamente por la misma Ley que previene la regla general.

La inmunidad fiscal, definida en estos términos, no existe ya en nuestro régimen de Haciendas locales, pues no puede concederse esta naturaleza a las exenciones de que disfruta la Iglesia, según tendremos ocasión de señalar más adelante. Sin embargo, como también hemos apuntado, no debe silenciarse que algunas de las exenciones que se pretende subsistan en la actualidad, contra la regla de contribución general a las cargas comunales, tienen unas motivaciones que las acercan mucho a las antiguas inmunidades personales, hoy ya felizmente desaparecidas.

C) EXENCIÓN FISCAL Y REMISIÓN IMPOSITIVA.

Al igual que en el Derecho civil, la remisión es un modo de extinción de las obligaciones tributarias; pero-como hace observar C. Albiñana (7)-por principio es inadmisible en el Derecho fiscal la remisión, pues para poderse acordar es preciso que la norma la autorice, y si ella la establece o permite, estamos ante el precepto excepcional que implica una renuncia a la deuda tributaria en favor o beneficio de algún contribuyente, negando o desconociendo el postulado de igualdad en la distribución de los gastos públicos.

Se admite, no obstante, la remisión-llamada también condonación -en materia punitiva, implicando un trato de favor para aquellos contribuyentes que declaren su verdadera situación tributaria; equivale, por tanto, en sus efectos prácticos a una exención parcial de la correspondiente exacción en cuanto afecta a la penalidad impuesta y no a las cuotas principales liquidadas. Tal es, en nuestra legislación fiscal local, el caso a que aluden los artículos 752 de la Ley de Régimen local y 269, párrafo 4, del Reglamento de Haciendas locales.

Aun con este carácter restringido, la diferencia entre la remisión y la exención es clara: la primera produce la extinción de la relación obligatoria ya nacida, al renunciar la Hacienda

(7) Trab. cít., pág. 233. 
a exigir el pago de la deuda fiscal; en cambio, la exención impide el nacimiento de la propia relación jurídica tributaria que había de dar lugar a la existencia y exigibilidad de la deuda impositiva de no darse aquélla. Una nota, sin embargo, es común a ambas instituciones: han de ser establecidas mediante normas de rango legislativo.

III. NATURALEZA Y ALCANCE DEL ARTICULO 719, A), DE LA LEY DE REGIMEN LOCAL

En el texto del antes transcrito artículo $719, a$ ), de la Ley de Régimen local se distinguen dos proposiciones jurídicas:

1. ${ }^{2} \quad$ La obligación de contribuir es siempre general en los limites de la Ley de Régimen local y, en consecuencia, ni las Corporaciones locales ni el Gobierno podrán declarar otras exenciones que las concretamente previstas $y$ autorizadas en ella, $y$

2. $\quad$ Debe tenerse por expresamente derogada toda otra exención actualmente en vigor, aunque se funde en razones de equidad, analogía o equivalencia, o en especial consideración de clase o fuero.

Tenemos, pues, de una parte, que este precepto obliga a las Corporaciones locales, en el momento de proceder a la imposición y ordenación de las exacciones, a sujetarse, en materia de exenciones, a los propios preceptos de la Ley de Régimen local, no pudiendo consignar en las Ordenanzas fiscales, sino exenciones concretamente previstas y autorizadas en ella. Ya hemos visto que este precepto, de tan terminante declaración, viene completado, en cuanto a la aplicación y efectividad de las exacciones, por el artículo 659, párrafo 1, de la Ley de Régimen local.

Pero además, el artículo $719, a$ ), a que nos venimos refiriendo, obliga también al Gobierno a no conceder exenciones más que dentro de los límites de las previstas en la citada Ley de Régimen local.

De otra parte, el artículo $719, a$ ), establece una verdadera disposición derogatoria de todas las exenciones a la sazón vigentes, la cual hay que entender alcanza a todas las no reconocidas 
expresamente en la Ley de Régimen local, cualquiera que sea su fundamento y el rango legal con que hubiesen sido concedidas, ya que el precepto no sólo no hace distinción alguna por la que pudiera filtrarse alguna excepción, sino que cuida expresamente de vedar la aplicación de exenciones no reconocidas en la Ley de Régimen local, aunque se funden en razones de equidad, equivalencia y clase o fuero, y rechaza expresamente también la aplicación analógica de las exenciones, de acuerdo con el principio de que éstas constituyen materia de interpretación estricta, o sea, que deben aplicarse en sus propios términos los preceptos que las establecen, ya que repugna a la naturaleza de la institución (excepción de la consecuencia jurídica derivada de una hipótesis general) toda aplicación de la norma con criterio analógico o extensivo.

Sin embargo, esta doble virtualidad-de derogación respecto al pasado y de prohibición para el futuro-que estimamos resulta claramente del texto del artículo $719, a)$, de la Ley de Régimen local, no fué reconocida por el Tribunal Supremo en la sentencia de 15 de noviembre de 1956, cuando declaró que «...el artículo 693 (se refería al texto articulado de 16 de diciembre de 1950, equivalente al 719 del texto refundido hoy vigente) es de contenido programático que obliga solamente a las Corporaciones locales en el trance de acordar la imposición y ordenar las exacciones, $y$ cuando con ese significado normativo determina que se tenga por expresamente derogada toda exención que en la actualidad de su promulgación estuviera en vigor, lo hace con referencia a las que hubieren podido ser acordadas por la misma Corporación o por el Gobierno, y entre ellas no se pueden incluir las que se hubieran concedido por una Ley, porque seria tanto como confundir en una sola dos fuentes de Derecho distintas, como son la Ley y el Gobierno, y porque, igualmente, el contenido de la disposición transitoria $9 .^{a}$ (del texto de 1950, idéntica a la $4 .^{a}$ del actual de 1955) hace referencia a las exenciones de origen convencional concedidas por los Ayuntamientos o por el Estado, sin aludir a las derivadas de la Ley».

No creemos equivocarnos al afirmar que la Ley de Régimen local en modo alguno quería decir-y desde luego no dice-lo 
que pretende en este fallo el Tribunal Supremo para dejar subsistentes los privilegios fiscales establecidos en el artículo 10 de la Ley de Mutualidades, de 6 de diciembre de 1941. En efecto, si no puede negarse que el artículo $719, a$ ), de aquélla, al disponer que «ni aquellas Corporaciones (locales) ni el Gobierno podrán declarar otras exenciones que las concretamente previstas y autorizadas en ella», se refiere verdaderamente, con finalidad programática, como apunta la citada sentencia, a las Corporaciones y al Gobierno para ordenarles que en el futuro no acuerden ni decreten, respectivamente, otras exenciones que las determinadas en la Ley, no es menos cierto que con la expresión «debiendo tenerse por expresamente derogada toda otra exención actualmente en vigor...», aquel precepto no se dirige ya especialmente a las Corporaciones locales ni al Gobierno, sino a todos -obsérvese que emplea el infinitivo impersonal «tenerse»-para derogar «toda otra exención actualmente en vigor», sin distinguir entre las establecidas en una Ley formal y las concedidas por una disposición administrativa, pues al no aparecer esa distinción en el precepto legal, no es lícito-como intenta el Tribunal Supremo-derivar de una frase en la que, si el precepto legal cita al Gobierno y a las Corporaciones locales, es sólo para prescribirles la conducta a seguir en el futuro en este aspecto; lo cual no podía ser de otro modo, toda vez que una Ley, por Ley formal que sea, si no es de rango constitucional, no puede vincular la futura actividad legislativa y sí sólo derogar, como sucede en este caso, las disposiciones legales existentes en la fecha de su promulgación.

La tesis sostenida en la sentencia de $\mathbf{1 5}$ de noviembre de $\mathbf{1 9 5 6}$ no podía prevalecer, y el mismo Tribunal Supremo la ha rectificado en la de 25 de marzo de 1961. En ésta se lee: «Que entrando en el estudio del fondo de la cuestión debatida, ha de convenirse en que ciertamente el artículo 719 de la Ley de Administración local, en su texto refundido de 24 de junio de 1955, establece una generalidad en la obligación de contribuir suficiente para que cualquier Ordenanza fiscal que se confeccionara al efecto hiciera caso omiso de los privilegios que a favor del Consejo ordenador de minerales especiales de interés militar estableció la suya fun- 
dacional de 1941, sin necesidad de respetar más que aquellos a que se refieren las numerosas excepciones a la regla general que en favor del Estado contiene el articulado de la Ley de 1955, entre las que son de señalar las que establecen sus artículos 439 , $\left.468,472, b) ; 498, d) ; 520,1 .{ }^{\circ}, a\right) ; 606,621$ y $\left.650,2 . \circ, a\right) \gg$. El fallo se refiere concretamente a la exención de toda clase de impuestos concedidos al citado C. O. M. E. I. M. por el artículo 14 de la Ley de 11 de julio de 1941. Queda, pues, claro que el Tribunal Supremo estima ya que la eficacia derogatoria del artículo $719, a$ ), alcanza también a las disposiciones generales con rango de Ley formal.

La conclusión que venimos sosteniendo queda confirmada, $a$ contrario sensu, por la disposición transitoria 9.a del texto articulado de 16 de diciembre de $1950\left(4 .^{2}\right.$ del texto refundido de 24 de junio de 1955). Según estas disposiciones, «las exenciones otorgadas por el Estado o los Ayuntamientos con anterioridad al 8 de marzo de 1924 (fecha de la promulgación del Estatuto municipal) y que contradigan los preceptos de esta Ley, seguirán, no obstante, en vigor, cuando se funden en título oneroso, pero serán redimibles en cualquier tiempo mediante indemnización a los beneficiarios de las mismas. La indemnización se fijará en una parte del precio pagado por los beneficiarios, proporcional a la parte no transcurrida del plazo de exención o en el valor estimado de las prestaciones que en el mismo tiempo hubiesen de realizar aquéllos a favor del Ayuntamiento por razón de exención».

Por consiguiente, la disposición transitoria $4 .^{a}$ de la Ley de Régimen local, al dejar en forma expresa subsistentes las exenciones onerosas o paccionadas a que concreta y especialmente se refiere, viene a confirmar la eficacia derogatoria del artículo 719 , a), respecto de todas las demás exenciones no recogidas a lo largo del articulado de la Ley.

Es más, el artículo 721, párrafo 1, de la Ley de Régimen local cuida de prevenir que «en lo sucesivo, cuando el Estado otorgue exención de derechos y tasas y arbitrios provinciales y municipales a alguna empresa o entidad, quedará subrogado en la obligación de abonar a la Corporación local respectiva el importe de los mismos con arreglo a los tipos de gravamen vigentes en la fe- 
cha del otorgamiento, salvo disposición legal en contrario». Nueva manifestación del carácter riguroso con que está trazado el precepto del artículo $719, a)$, de la Ley.

Para precisar debidamente el alcance de la indicada derogación y prohibición, contenidos en el artículo $719, a$ ), conviene so-

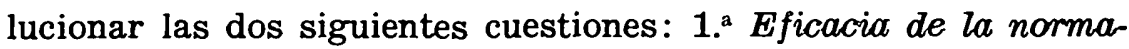
tiva de la Ley de Régimen local frente a otras disposiciones que hayan establecido o establezcan exenciones fuera de los límites permitidos por aquélla, y 2. ${ }^{\mathrm{a}}$ Momento en que entraron en vigor tales derogación y prohibición, o los diversos momentos, si fueron reiterados.

A) Respecto de la primera cuestión, nos parece evidente que, en virtud del principio de legalidad o jerarquía de las fuentes, propio del Estado de Derecho, la eficacia o fuerza de prevalecer de la normativa de la Ley de Régimen local en punto a exenciones tributarias, frente a las disposiciones que la desconocen o contrarían, es máxima, como establecida en una verdadera Ley formal.

La Ley de Régimen local es-valga la redundancia-una verdadera Ley, en sentido formal, emanada del poder legislativo del Estado. No cabe considerarla como una simple disposición administrativa por el mero hecho de que su texto articulado de 16 de diciembre de 1950 fuera aprobado por Decreto, y de que el vigente texto refundido de 24 de junio de 1955 fuera publicado por Decreto de esa fecha del Ministerio de la Gobernación, recogiendo la nueva redacción del Libro IV, «Haciendas locales», y de algunos otros artículos, pues aparte de que la Ley de 17 de julio de 1942, que creó las Cortes españolas, respeta las altas atribuciones legislativas que confirieron al Jefe del Estado las Leyes de 30 de enero de 1938 y 8 de agosto de 1939, no hay que olvidar la existencia, en nuestro país, de la práctica de la llamada legislación delegada, la cual viene utilizándose, por razones técnicas, para el desarrollo de las leyes de bases y en los casos de autorizaciones al Gobierno para realizar refundiciones legales. A este respecto, recuerda GaRRIDO FaLla (8) que las leyes de bases son

(8) Tratado de Derecho administrativo. Madrid, 1958, tomo I, pág. 227. 
reglamentaciones que realiza el poder legislativo ordinario sobre una determinada materia, conteniendo una autorización al Gobierno para que dichas bases sean desarrolladas más minuciosamente mediante un texto articulado que, una vez dictado, tiene valor de Ley formal; y que las autorizaciones para realizar refundiciones legales habilitan al Gobierno para reunir en un texto íntegro (que en adelante será el único aplicable) disposiciones dispersas - y a veces de distinto rango-sobre una determinada materia: también la refundición tiene valor de Ley.

Pues bien, caso peculiar de delegación legislativa para el desarrollo de bases ha sido precisamente el que nos brindó la Ley de 17 de julio de 1945, que, al aprobar las bases del régimen local, autorizó al Gobierno para dictar un texto articulado que fué el aprobado por Decreto de 16 de diciembre de 1950; este texto aprobado por Decreto tenía, pues, valor de Ley formal. Supuesto característico de autorización para realizar una refundición legal

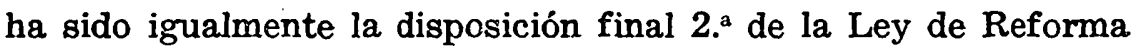
de las Haciendas locales, de 3 de diciembre de 1953, que dispuso que «en el plazo de tres meses, el Ministerio de la Gobernación publicará un texto refundido de la Ley de 16 de diciembre de $1950 \mathrm{y}$, sucesivamente, los Reglamentos afectados por ella». En cumplimiento de dicho precepto-aunque no respecto del plazo que el mismo señala-se promulgó el Decreto de 24 de junio de 1955, por el que se aprobó el vigente texto refundido de la Ley de Régimen local. Este tiene también, por tanto, valor de Ley formal; no es ya una fuente de la Administración o dispcsición administrativa, sino una fuente para la Administración, emanada del poder legislativo.

L.a Ley de Régimen local es-repetimos_una Ley formal. Según el artículo 5. del Código civil, las leyes sólo se derogan por otras leyes posteriores. Pero debe recordarse que la Ley de Régimen local goza de una normativa especial en cuanto se refiere a su derogación. En efecto, la disposición final 2.: del texto articulado de 16 de diciembre de 1950 decía ya que «los preceptos de esta Ley sólo podrán ser modificados por otra disposición de igual rango en que expresamente se haga constar el artículo o axtículos que se modifican o adicionan. Cuando el número de al- 
teraciones lo aconseje, el Ministro de la Gobernación podrá publicar un texto refundido». $\mathrm{Y}$ la disposición final $4 .^{2}$ del texto refundido de 24 de junio de 1955 establece que «los preceptos de esta Ley que sean reflejo de los principios esenciales comprendidos en las bases de 17 de julio de 1945 y 3 de diciembre de 1953, y cuya modificación implique la de aquéllos, sólo se podrá variar o alterar mediante otra ley de bases en la que se declare concretamente el alcance de la reforma».

En concordancia con estos preceptos y también para fundamentar la solución de la cuestión que tenemos planteada, deben citarse algunos artículos de la Ley de Régimen jurídico de la Administración del Estado, texto refundido de 26 de julio de 1957. Así, el artículo 26 de la misma establece que «la Administración no podrá dictar disposiciones contrarias a las leyes, ni regular, salvo autorización expresa de una Ley, aquellas materias que sean de la exclusiva competencia de las Cortes», y el 28 dice que: «serán nulas de pleno derecho las disposiciones administrativas que infrinjan lo establecido en los articulos anteriores». Ha de recordarse también que, según el artículo 23, párrafo 2, del mismo texto legal, el Decreto, salvo el caso ya apuntado en que se utilice para que la Jefatura del Estado, en el uso de sus prerrogativas de carácter legislativo, apruebe una Ley, es una simple «disposición administrativa de carácter general» $y$, por tanto, sometida y subordinada en su eficacia a la Ley en el orden jerárquico de las fuentes jurídicas, sin que, por consiguiente, pueda derogar ni contrariar en ningún caso lo establecido por las leyes formales.

En base a las consideraciones anteriores podemos concluir, respecto de la primera cuestión enunciada, que el artículo $719, a$ ), de la Ley de Régimen local tiene plena eficacia para:

1. Derogar todas las disposiciones anteriores a la entrada en vigor de la Ley de Régimen local, aun con carácter de Ley formal, que reconocían exenciones fiscales no recogidas a lo largo del articulado de la propia Ley y de la disposición transitoria $4 .^{\mathrm{a}}$ de la misma.

No se diga, de contrario, que la Ley de Régimen local es una Ley general $y$, en consecuencia, en virtud del principio lex pos- 
terior generalis non derogat legi priori spaciali, no puede derogar las exenciones establecidas por disposiciones de carácter especial, pues si esto puede ser cierto en el caso de que se tratara de derogación implícita, no tiene eficacia alguna cuando la Ley general contiene un precepto derogatorio explícito, cual ocurre con la Ley de Régimen local y su artículo $719, a$ ).

2. Prohibir, bajo sanción de nulidad, que después de la promulgación de la Ley de Régimen local se establezcan, mediante fuente legal distinta de la Ley formal, otras exenciones fiscales que no sean las concretamente determinadas en el articulado de aquélla.

B) Con relación al segundo problema planteado, es decir, en qué momento se produjeron los plenos efectos derogatorios y prohibitivos que derivan del artículo $719, \alpha$ ), de la Ley de Régimen local (antes art. 693, a), del texto articulado de 16 de diciembre de 1950), hemos de traer aquí la cita de las siguientes normas:

- La disposición final del Estatuto municipal, que estableció la entrada en vigor de éste a partir del día 1 de abril de 1924 .

- La disposición final 1. ${ }^{\mathrm{a}}$ del texto articulado de 16 de diciembre de 1950, según la cual, «la presente Ley entrará en vigor el día 1 de marzo de 1951...».

- La disposición final $1 .^{\mathrm{a}}$ del texto refundido de 24 de junio de 1955, a cuyo tenor, «los efectos de la presente Ley se entenderán referidos al 1 de enero dè $1954 \ldots$ »

Obsérvese que excluímos de esta enumeración el Decreto de 25 de enero de 1946, por el que se dió ordenación provisional a las Haciendas locales, y que contenía un precepto, el artículo $268, a$ ), idéntico al actual artículo $719, a$ ), de la Ley de Régimen local; entendemos que esa exclusión es procedente, porque tal Decreto, simple ordenación provisional de las Haciendas locales, como el mismo se titula, no puede producir los efectos de una Ley formal, toda vez que la Ley de Bases de Régimen local, en su disposición final, sólo autorizó al Gobierno para dictar las disposiciones precisas a fin de ejecutar las bases 8,9 y 38, con independencia del texto articulado de la Ley, y es obvio que ninguna de estas bases se refería a exenciones fiscales. 
En conclusión, respecto de este punto, tenemos:

1. Los efectos derogatorios que derivan del artículo $719, a)$, de la Ley de Régimen local se produjeron:

1.1. El día 1 de abril de 1924, respecto de las disposiciones de todo rango anteriores a esa fecha.

1.2. El día 1 de marzo de 1951, respecto de las disposiciones de todo rango promulgadas desde el día 1 de abril de 1924 hasta aquella fecha, $y$

1.3. El día 1 de enero de 1954, respecto de las disposiciones de todo rango dictadas con posterioridad al 1 de marzo de 1951 y hasta la expresada fecha.

2. Los efectos prohibitivos que resultan del artículo $719, a)$, de la Ley de Régimen local se iniciaron el día 1 de abril de 1924 y perduran en la actualidad, nuevamente confirmados y ratificados por la Ley de Régimen local, en sus dos versiones de 16 de diciembre de 1950 y 24 de junio de 1955.

\section{EXENCIONES CONCRETAS EN MATERIA DE HACIENDA MUNICIPAL}

Indicadas en el apartado anterior las conclusiones a que, a nuestro juicio, nos llevan el sentido y alcance del artículo 719, a), de la Ley de Régimen local, corresponde ahora, para completar nuestro trabajo, exponer concretamente las diversas exenciones que figuran en la legislación española en relación a la Hacienda municipal, y nos referiremos, no solamente a las exenciones reconocidas en forma expresa en la Ley de Régimen local y textos complementarios, sino también a las contenidas en otras disposiciones, legales o simplemente administrativas, destacando, en su caso, de acuerdo con aquellas conclusiones, las dudas que puede ofrecer la licitud de seguir aplicando algunas de las disposiciones que vamos a enumerar.

A) EXENCIONES RECONOCIDAS EXPRESAMENTE EN LA LEY DE
RÉGIMEN LOCAL Y OTROS TEXTOS COMPLEMENTARIOS.

Las exenciones reconocidas por la Ley de Régimen local y disposiciones que la complementan, respecto a las exenciones municipales, son las siguientes: 
1. ${ }^{2}$ Derechos $y$ tasas.

A) Exenciones potestativas para los Ayuntamientos: artículos 438 y 446, párrafo 2, c), de la Ley de Régimen local; artículo 217, párrafo 3, del Reglamento de Haciendas locales.

B) Exenciones obligatorias para los Ayuntamientos: artículo 439 de la Ley de Régimen local; artículos 9 y 10, párrafo 7, del Reglamento de Haciendas locales (véanse también las sentencias de 2 de diciembre de 1931, 28 de octubre de 1946 y 5 de junio de 1956).

2. Contribuciones especiales.

A) Por aumentos determinados de valor: artículo 468 de la Ley de Régimen local.

B) Por otros conceptos: artículo 472 de la Ley de Régimen local; artículo 45 del Reglamento de Haciendas locales. (V. tam. bién el artículo 65 de la Ley especial de Barcelona, y el 10, párrafo 3, de su Reglamento de Hacienda.)

3. ${ }^{\mathrm{A}} \quad$ Impuesto de Consumos de lujo: artículo 479, párrafo 2, de la Ley de Régimen local.

4. ${ }^{2} \quad$ Recargo sobre el Impuesto de consumo de gas y electricidod: artículo 489, párrafo 3, de la Ley de Régimen local.

5. $\quad$ Recargo sobre el Impuesto del 3 por 100 sobre el producto bruto de las explotaciones mineras: artículo 491, párrafo 3, de la Ley de Régimen local.

6. ${ }^{\text {a }} \quad$ Arbitrio sobre Casinos y Circulos de recreo: artículo 497 de la Ley de Régimen local; artículo 69, párrafo 2, del Reglamento de Haciendas locales (9).

7. a Arbitrio sobre carruajes $\approx$ caballerias de lujo y velocipedos: artículo 498, párrafos 4, 10 y 11, de la Ley de Régimen local; artículos 73 y 75 del Reglamento de Haciendas locales.

8. Arbitrio sobre solares sin edificar.

A) Exenciones potestativas para los Ayuntamientos: artículo 504, párrafo 3, de la Ley de Régimen local.

(9) Como hemos dicho en el apartado IE, A), de este trabajo, ests s:puesto, más que una exención, es una delimitación de la figura tributaria legal por va negativa o de exclusión, ya que si una sociedad tiene exclusivamente un fin sccial, educativo o benéfico, deja de ser un casino o círculo de recreo. 
B) Exenciones obligatorias para los Ayuntamientos: artículo 504, párrafos 1 y 2, de la Ley de Régimen local.

9. Arbitrio sobre el incremento del valor de los terrenos: artículos 520,521, párrafos 1 y 2, y 523 de la Ley de Régimen local.

10. Arbitrio sobre el consumo de bebidas espirituosas y alcoholes.

A) Exenciones potestativas para los Ayuntamientos: artículo 544, párrafo 3, de la Ley de Régimen local.

B) Exenciones obligatorias para los Ayurtamientos: artículos 531, párrafo 3, y 544, párrafo 2, de la Ley de Régimen local.

11. Arbitrio sobre el consumo de carnes, volateria y caza menor: artículos 531, párrafo 3 , y 548, párrafo 2 , de la Ley de Régimen local (10).

12. Arbitrio sobre pescados y mariscos finos: artículo 531, párrafo 3 , de la Ley de Régimen local.

13. Arbitrio sobre pompas fúnebres: artículo 555, párrafo 3, de la Ley de Régimen local.

14. Arbitrio sobre riqueza urbana: artículo 558, párrafo 2, de la Ley de Régimen local.

15. Arbitrio sobre riquezas ristica y pecuaria: artículo 562, párrafo 3, en relación al 558, párrafo 2 , de la Ley de Régimen local.

16. Prestación personal y de transportes: artículo 565 de la Ley de Régimen local (11).

(10) Igualmente bemos indicado en dicho apartado $\Pi$, A), que en el párrafo 1 de este artículo 548 (que dice: «estarán exentas del arbitrío las especies en tránsito, las reses que no se destinen al sacrificio y las carnes de las sacrificadas para la explotación fuera del Municipio de la imposición») se establece una delimitación de la hipótesis de hecho de la norma tributaria (el consumo de las especies gravadas en el término municipal) por via negativa o de exclusión. No configura, pues, en puridad de términos, una exención.

(11) También hemos señalado en el apartado $I I$, A), de este trabajo que el artículo 565 de la Ley de Régimen local delimita por vía negativa o de exclusión las personas sujetas a la prestación personal. Hay que estimar, por tanto, que no se trata de una exención en sentido propio. 
17. Arbitrio sobre los solares edificados y sin edificar: artículo 590, párrafos 7 y 8, de la Ley de Régimen local.

18. Arbitrio sobre ordenación urbanistica: artículo 184, párrafo 4, de la Ley del Suelo (12).

19. Arbitrio sobre el aumento de volumen de edificación: artículo 187, párrafo 3, de la Ley del Suelo.

20. Arbitrios municipales en general: artículo 720 de la Ley de Régimen local. (V. el siguiente apartado B), 5.)

\section{B) EXAMEN ESPECífico DE LAS EXENCIONES habitualmiente INVOCADAS.}

\section{Exenciones paccionadas.}

En el apartado III anterior ya nos hemos referido a la disposición transitoria 9. ${ }^{a}$ del texto articulado de la Ley de 16 de diciembre de 1950 (que es la $4 .^{\text {a }}$ del texto refundido de 24 de junio de 1955), la cual es reproducción casi literal de la correlativa disposición transitoria 11 del Estatuto municipal, de 8 de marzo de 1924, que decía así: "Las exenciones otorgadas por el Esiado - los Ayuntamientos con anterioridad a la fecha de promulgación de esta Ley, y que contradigan sus preceptos, seguirán, no obstante, en vigor cuando se funden en titulo oneroso, pero serán redimibles en cualquier tiempo mediante indemnización a los beneficiarios de las mismas. La indemnización se fijará en una parte del precio pagado por los beneficiarios proporcional a la parte no transcurrida del plazo de exención, o en el valor estimado de las prestaciones que en el mismo tiempo hubiesen de realizar aquéllos a favor del Ayuntamiento por razón de exención».

En el texto del mismo Estatuto figura, bajo el artículo 318 (recogido en términos análogos, a través de la legislación intermedia, por el art. 719, d), de la ت̇ey de Régimen local), ia prescripción de que «será nulo todo pacto o contrato ajustado por

(12) A pesar de los términos en que el precepto se produce ( $\ll$ no estarán sujetos al arbítrio...»), estimamos se trata de una verđađera exención, a detallar en la correspondiente Ordenanza. 
los Ayuntamientos y que tenga por objeto la obligación de contribuir, la forma o la cuantía de las exacciones municipales»; y también el artículo 319 que, como hemos dicho en el apartado I de este trabajo, inspiró el actual artículo $719, d$ ), de la Ley de Régimen local.

Por consiguiente, el Estatuto municipal establecía ya la prohibición total de los pactos sobre exenciones fiscales, aunque reconocía la validez de los existentes antes de su promulgación, si bien los declaraba redimibles (13).

Fuera de los casos en que sean aplicables la disposición transitoria 11 del Estatuto municipal, la 9. ${ }^{a}$ del texto articulado de 1950 y la $4 .^{\text {a }}$ del refundido de 1955, habrán de estimarse nulos de pleno derecho los pactos o contratos que establezcan exencio-

(13) La subsistencia de exenciones paccionadas ha sido reconocida por el Tribunal Supremo en varios fallos. Citemos los siguientes:

El de 28 de noviembre de 1933, que en virtud de la concesión de unas obras de saneamiento y mejora interior, sustrajo del arbitrio de plus valía un solar adquirido por la Compañía concesionaria, sito en la zona de concesión.

El de 6 de diciembre de 1948, que exime del pago del arbitrio sobre solares a una Compañía de Tranvias, en base a la existencia de un contrato bilateral y oneroso entre el Ayuntamiento y aquélla, con pactos que implican la imposibilidad de aplicar cargas, gravámenes, arbitrios o imposición en general que, de una manera directa $o$ indirecta, constituyen o pueden constituir modificación que agrave las condiciones de onerosidad de la convención estipulada.

El de 6 de diciembre de 1949, que declaró exenta a otra Compañía de Tranvias urbanos del pago de derechos y tasas por ocupación del suelo, subsuelo y vuelo de la vía pública, con fundamento en la circunstancia de haberse estipulado la exención como cláusula de la concesión y con anterioridad a la entrada en vigor del Estatuto municipal.

El de 24 de febrero de 1954, que si bien respetó las exenciones convenidas como consecuencia de un contrato de suministro de electricidad para el alumbrado público, durante la vigencia de éste, declaró la licitud del derecho del Ayuntamiento a requerir a la empresa, una vez terminado el contrato con sus prórrogas, a que se sometiera a las disposiciones legales comunes por haber caducado el estado de beneficio que en este orden se habia acordado mediante contrato a la empresa suministradora de flúido eléctrico.

Finalmente, el de 14 de marzo de 1959, que considera redimible la exención fiscal concedida a Sociedad General de Aguas de Barcelona en el convenio otorgado entre dicha Sociedad y el Ayuntamiento de Esplugas de Llobregat el año 1905, si bien mediante el cumplimiento de los requisitos establecidos en la Ley de Régimen local. 
nes fiscales contra las conclusiones a que hemos llegado en el apartado anterior.

2. Exenciones a favor de la Iglesia.

Como recuerda VizueTe GALlego (14), en España, con anterioridad a la vigencia del Concordato de 1953, no existía un principio general sobre inmunidad fiscal de la Iglesia, como reconocieron las Reales Ordenes de 7 de abril de 1926 y 5 de marzo de 1928, entre otras, por lo que debía acudirse en cada caso a las disposiciones especiales que regulaban la exacción de que se tratara. Hoy rige, aparte de los preceptos ya citados de la Ley de Régimen local, que reconocen exenciones a favor de la Iglesia, el Concordato entre la Santa Sede y el Estado español, suscrito el 27 de agosto de 1953 y ratificado por Instrumento de 26 de octubre del mismo año. Es de citar, a nuestro objeto, el artículo $\mathrm{XX}$ de dicho Concordato.

La Iglesia, como sujeto, no goza de exención fiscal absoluta; tampoco tienen reconocida exención tributaria general los bienes de la Iglesia ni existe exención personal a favor de los clérigos, sino que el Concordato establece concretamente la exención en cada caso en orden a determinados bienes y actividades. Así, los párrafos 1 y 2 del citado artículo $\mathrm{XX}$ tienen un alcance predominantemente objetivo y se refieren a cosas y bienes de la Iglesia y sus instituciones, y el párrafo 3 puede considerarse de primordial significación subjetiva en cuanto alude a las dotaciones del culto y clero y al ejercicio del propio ministerio sacerdotal.

De acuerdo con las disposiciones del Concordato, el texto refundido de la Ley de Régimen local, de 24 de junio de 1955, reconoce varias exenciones a favor de la Iglesia, como son: contribuciones especiales, artículos 468 y 472; arbitrio sobre el incremento del valor de los terrenos, artículo 520; arbitrio sobre riqueza urbana, artículo 558; arbitrio sobre solares sin edificar,

(14) «Sobre las relaciones de la Iglesia con el Municipio», en REvista DE ESTudios de LA Vida LoCal, 1961, núm. 120, pág. 822. 
artículo 504; arbitrio sobre solares edificados y sin edificar, artículo 590 (15).

\section{Exenciones a favor del Estado.}

El Estado no goza de exención general de las exacciones municipales. No obstante, por razón de determinados bienes y actividades, está exento de algunas exacciones, según reconoce expresamente la Ley de Régimen local (16).

(15) El Tribunal Supremo, por sentencia de 27 de junio de 1950, ha declarado, en relación a un caso de arbitrio de plus valía que recaía sobre adquirente de bienes de la Iglesia, que la exención tributaria de que disfrutan estos bienes «la tienen en razón a su posesión; por ello, y por consecuencia, deja de tener efectividad cuando salen de su patrimonio estático o de manos muertas para entrar por su transmisión en el dinamismo del comercio de los hombres, pasando a la propiedad de personas que por sí no disfrutan de exención tributaria».

(16) Recuérdese, pues, que el Estado está exento:

- de derechos y tasas, en los casos y términos del artículo 439;

- de contribuciones especiales por aumento de valor, en los términos del artículo 468;

- de contribuciones especiales por otros conceptos, en los términos del artículo 472;

- del recargo del 3 por 100 sobre el producto bruto de las explotaciones mineras, en el caso del artículo 490 , párrafo 3 ;

- del arbitrio sobre carruajes, caballerias de lujo y velocipedos, en los términos del artículo 498, párrafo 10, d);

- del arbitrio sobre solares sin edificar, en los términos del artículo 504, párrafo 1;

- del arbitrio sobre el incremento del valor de los terrenos, en los términos del artículo 520, párrafo 1, a);

- del arbitrio sobre la riqueza urbana, en los términos del artículo 558, párrafo 1, y

- del arbitrio sobre solares, estén o no edificados, en los términos del art́́culo 590, número 8.?

La jurisprudencia ha venido recalcando el carácter especifico de dichos beneficios fiscales y la ausencia de una exención general, y asi:

- la sentencia de 6 de abril de 1948 denegó la exención a una Confederación hidrográfica;

- la sentencia de 14 de enero de 1955 declaró que el Estado no está exento de satisfacer contribuciones especiales por sus edificios civiles (escuelas);

- la sentencia de 31 de octubre de 1955, relativa al arbitrio sobre el incremento del valor de los terrenos, sostiene que el Estado (Ministerio del 
4. Exenciones a favor de F.E.T. y de las J.O.N.S. y Delegación Nacional de Sindicatos.

A este respecto, son de citar el artículo 1. de la Ley de 6 de noviembre de 1941 y el Decreto de 27 de abril de 1951, que equipara al Estado, a efectos tributarios, a F. E. T. y de las J. O. N. S. y a las Delegaciones sindicales y Centrales nacional-sindicalistas.

\section{Exenciones a favor de «Ayuda americana».}

Arrancan del Convenio de 26 de septiembre de 1953, entre los Gobiernos de los Estados Unidos de América y de España, para la Mutua defensa y Ayuda económica, cuyo artículo 3. y Anexo técnico, párrafo 1, las establecen «sobre los productos, propiedades, materiales o equipo importados en su territorio como consecuencia de este Convenio o de algún otro similar entre el Go-

Ejército) no está exento, si es el adquirente, porque el impuesto recae en el enajenante, contra el que puede repercutir, y, sobre todo,

- la sentencia de 25 de marzo de 1961, transcrita parcialmente en el apartado II de este trabajo, que se refiere a que la Ley de Régimen local deroga los privilegios establecidos a favor del Consejo ordenador de minerales especiales de interés militar por la Ley fundacional de 11 de julio de 1941 .

La jurisprudencia ha declarado también que las exenciones a favor del Estado se extienden a las empresas contratistas de sus obras que se subroguen en la personalidad de aquél. Así, la sentencia de 17 de abril de 1956 dice que «esta Entidad, como contratista de ellas (obras), ha de gozar, según doctrina generalmente admitida en materia administrativa, de todas las exenciones que correspondan al Estado o Entidad de carácter público, en cuyo puesto y lugar se subroga»; y la de 26 de mayo de 1958, abundando en lo establecido en las de 2 de diciembre de 1931, 21 de diciembre de 1955 y 17 de abril de 1956, declara que «la exención de derechos y tasas concedida al Estado alcanza a los contratistas de sus obras, puesto que la Ley autoriza que éstas se lleven a cabo, no sólo por administración, sino por contrata..., subrogándose en esta astividad en los derechos y obligaciones del mismo» (Estado).

Es importante hacer notar que a pesar de la amplia declaración de la sentencia de 17 de abril de 1956 (que habla de todas las exenciones), los fallos citados se refieren a exenciones de derechos y tasas, coincidienco, pues, con lo que $\in \mathbf{n}$ la actuaiidad ya dispone el artículo 9.2 del Reglamento de Haciendas locales, oportunamente citado. 
bierno de los Estados Unidos y el de cualquier otro país que re. ciba asistencia militar».

Las prescripciones de este Convenio han sido desarrolladas por disposiciones posteriores (Decreto de 22 de enero de 1954 $\rightarrow$ complementado por.la Orden de 5 de julio de 1955-y Ordenes de 9 de abril y 9 de septiembre del mismo año).

En el texto refundido de la Ley de Régimen local, de 24 de junio de 1955, se incluyó un nuevo artículo, el 720, citado ya en el epígrafe A), 20, de este apartado, en el que se reconoce que «de conformidad con el Anexo único al Convenio relativo a la ayuda para la mutua defensa, firmado con Norteamérica en 26 de septiembre de 1953, se declara la exención de toda clase de arbitrios provinciales y municipales respecto de las actividades y gastos que se ejecuten dentro de la jurisdicción del Gobierno español, por o en nombre de los Estados Unidos, para la defensa común, en los términos y con las limitaciones expresadas en dicho Anexo»(17).

(17) Por Decreto de 11 de junio de 1954 se constituyó en el Ministerio de Asuntos Exteriores sla Comision Interministerial para el Auxilio Internacional a la Infancia, que emitíá dictamen y, en su caso, propondrá la resolución pertinente en todo lo relativo a la ejecución práctica de los principios insertos en el Convenio celebrado el 7 de mayo de 1954 (no publicado) entre el Gobierno español y el Fondo de las Naciones Unidas para la Infancia, a la preparación y elaboración definitiva de los planes de operaciones consiguientes, y a la correspondiente utilización y distribución satisfactorias de los artículos o socorros que el Fondo pueda facilitar».

Por Decreto de 13 de diciembre de 1954 se extendieron las facultades de dicha Comision Interministerial a los suministros que haga la organización «Caritas» norteamericana (NCWC) a «Caritas» espanola (Secretariado Nacional de Caridad de la Acción Católica), y se dispuso que elos suministros a que se refiere el presente Decreto gozarán de los beneficios y exenciones previstos en el artículo $7 .^{\circ}$ del Convenio concertado por el Gobierno español y el Fondo de las Naciones Unidas para la Infancia».

Por Orden de 4 de febrero de 1955 se dictaron las normas para el desarrollo del programa de Ayuda Social Americana, que se conocerá para todos los efectos, tanto oficiales como particulares, bajo la rúbrica \&Ayuda Social Americana (NCWC)-Caritas Española». La norma 8." de dicha Orden dispone que «el Comité ejecutivo responderá ante la Comisíbn Interministerial de que la Ayuda Social se desarrolla en debida forma y vigilará directamente o por medio de las Jefaturas de los organismos colaboradores para que se cumplan los requisitos siguientes: a) Exención de toda clase de impuestos, arbitrios y tasas...» 
Las exenciones a favor de la Ayuda Social Americana no vienen reconocidas en la Ley de Régimen local de 24 de junio de 1955, si bien podrían acordarlas los Ayuntamientos en cuanto a los derechos y tasas, en virtud de lo dispuesto en el artículo 438 de aquélla, citado en el apartado A), 1., y según el cual, los Ayuntamientos tienen la facultad de otorgar la exención total o parcial de los derechos y tasas, aun en los casos en que su exacción, en general, sea obligatoria, cuando el servicio o aprovechamiento correspondiente afecte de modo principal a las clases productoras de escasa capacidad económica y el interés puiblico to justifique (18).

6. Exenciones a favor de las industrias de interés nacional.

Las establecen, con carácter parcial (reducción del 50 por 100) y temporal (quince años), las siguientes disposiciones: Ley de 24 de octubre de 1939 , sobre protección a las industrias de interés nacional, artículo 2.o; Ley de 25 de septiembre de 1941, por la que se creó el Instituto Nacional de Industria, artículo 18; su Reglamento de 22 de enero de 1942; Decretos de 14 de marzo de 1947, s: de enero de 1950,20 de julio de 1954 y 29 de abril de 1955 y Orden de 9 de noviembre de 1956 (19).

(18) El Ministerio de la Gobernación, por resolución de 10 de febrero de 1955 (inserta en el «Boletín Oficial de la Provincia» de Zaragoza, de 18 del propio mes y año), dictada a consulta del Ayuntamiento de Granada y a la que dió carácter de interés general, dispuso, en méritos del artículo 7. del aludido Convenio de 7 de mayo de 1954, artículo 438 de la Ley de Régimen local y Decreto de 13 de diciembre de 1954, que los suministros de artículos alimenticios facilitados tanto por el Fondo de las Naciones Unidas para la Infancia, cuanto por la entidad norteamericana «Conferencia Católica Nacional para el Bienestar», gocen del beneficio de exención de los derechos o tasas por el servicio de inspección y reconocimiento sanitario de mantenimientos destinados al abasto público.

(19) La jurisprudencia del Tribunal Supremo ha abundado en el criterio del Gobierno, adelantándose incluso a su formulación expresa: y aś, por sentencia de 7 de junio de 1951, antes de que apareciera la primera cisposición (el Decreto de 20 de julio de 1954) que aclaró que la Ley ơe 24 de octubre de 1939 se refería a toda clase de exenciones e impuestos provinciales y municipales, afirmo que las industrias declaradas de interés zactonal gozan de la bonificación del 50 por 100 respecto del «arbitrio 


\section{Exenciones a favor de viviendas.}

1. Casas baratas.-Deben citarse el artículo 20 del Real Decreto-ley de 10 de octubre de 1924, texto básico regulador en materia de casas baratas, y el artículo 1.9 del Real Decreto-ley de 15 de agosto de 1927, sobre casas para funcionarios. Véase también la sentencia del Tribunal Supremo de 7 de octubre de 1946.

La Ley de Régimen local, al regular el arbitrio de plus valía, alude expresamente a las casas baratas, al disponer en su artículo 520 que estarán exentos del mismo «los terrenos acogidos a la Ley de Casas baratas durante los periodos de veinte a treinta años, según los casos, establecidos en el Real Decreto-ley de 10 de octubre de 1924, a partir de su calificación, así como los terrenos aprobados para la construcción de aquéllas, mien-

de licencia de apertura de establecimientas, al amparo del apartado b) del artículo $2 .^{\circ}$ de la Ley de 24 de octubre de 1939.

Por sentencia de 20 de octubre de 1956, posterior, por tanto, a la promulgación de los textos articulado y refundido de la Loy de Régimen local, el Tribunal Supremo declaro que la Empresa Nacional Calvo Sotelo y, en general, todas las entidades encuadradas en el I. N. I., tienen derecho a la bonificación del 50 por 100 en el arbitrto de plus valia, sal tratarse en definitiva de un impuesto netamente municipal», con base en la Ley de 25 de septiembre de 1941, Reglamento de 22 de enero de 1942 y Decreto de 14 de marzo de 1947.

EH fallo de 22 de diciembre de 1958 afirmo que una industria declarada de interés nacional gozará de la reducción del 50 por 100 en los derechos y tasas por ocupación del suelo, subsuelo y vuelo de la via pública, conforme al apartado $b$ ), artículo $2 .{ }^{\circ}$, de la Ley de 24 de octubre de 1939 y al Decreto de 20 de julio de 1954.

No obstante, en ninguna de estas sentencias del Tribunal Supremo se planté el problema de la fuerza derogatoria al respecto de la Ley de Régimen local. A pesar del contenido y doctrina sentada en las citadas declaraciones jurisprudenciales, nuestro criterio, demostrado en el apartado III de este trabajo, es el siguiente: la exención parcial a favor do las industrias o empresas declaradas de interés nacional quedó derogada por la Ley de Régimen local, y las disposiciones posteriores a la misma no pueder prevalecer contra lo ordenado en una Ley formal. Obsérvese que la única disposición relativa a esta materia, posterior al texto refundido de dicha Ley, es una simple Orden ministerial (la de 9 de noviembre de 1956) que, ante las fundadas dudas que habian surgido acerca de la subsistencia de aquella exencín parcial, intentó aclararlas y resolverlas-a nuestro juicio, erróneamente-. 
tras conserven esta aprobación». No obstante, y aunque la Ley cie Régimen local no lo declare de un modo explícito, la exención que estas casas baratas gozan respecto de la contribución territorial lleva aparejada también, en virtud de lo dispuesto en sus artículos 504, 558 y 590, su exención de los arbitrios sobre solares sin edificar, sobre la riqueza urbana y sobre los solares estén o no edificados. Más dudoso es que lo estén también, como veremos seguidamente al tratar de los restantes tipos de vivienda social, de los derechos y tasas y de las contribuciones especiales.

2. Viviendas protegidas.-Son de citar el artículo 5.9 de la Ley de 19 de abrii de 1939, el artículo 25 del Reglamento de 8 de septiembre de 1939 y la Ley de 25 de noviembre de 1944, que establecen la exención del 90 por 100 de toda contribución, impuesto o arbitrio, ya sea del Estado, Provincia o Municipio, que graven las casas durante veinte años. Pueden verse también las sentencias de 23 de febrero de 1952, 7 de noviembre de 1957 y 9 de abril de 1958.

3. Viviendas bonificables. - Análogamente, establecen una reducción del 90 por 100 en el importe de exacciones municipaies las siguientes disposiciones: artículo 6.o de la Ley de 25 de noviembre de 1944, artículo 18 de la Orden de 30 de marzo de 1948, artículo 7.: del Decreto-ley de 19 de noviembre de 1948 (v. también las sentencias de 20 y 23 de septiembre de 1957), artículo 3.9 del Decreto-ley de 27 de noviembre de 1953 , y norma $7 .^{a}$ de la Orden de 10 de julio de 1954 (20).

(20) Por lo demás, la jurisprudencia, fundándose en la discutida doctrina de que, históricamente, la palabra «arbitrio» tiene un sentido genérico de tributo municipal, que comprende las tasas, y de que si a partir del Estatuto el término genérico es exacción, es porque se comprende a las multas, que no tienen carácter tributario, aparte de la norma interpretativa del artículo $3 .^{\circ}$ del Decréto-ley de 27 de noviembre de 1953, deciaró en reiteradas sentencias que las viviendas bonificables están exentas parcialmente del pago de derechos y tasas (sentencias de 13 de aril y 26 àe mayo de 1954, 29 ce octubre de 1955, 30 de junio y 11 de diciembre cie 1956 y 20 de septiembre, 10 de octubre y 24 de noviembre de 1957). No obstante, la sentencia de 16 de enero de 1950 , con criterio nấs riguroso,

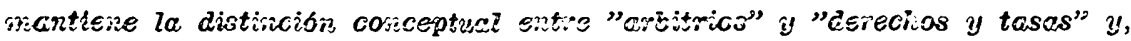
en concesinencix, declara que la bonificacicin del 90 por 100 de los derechos 
4. Viviendas de renta limitada.-Véase el artículo 13 de la Ley de Protección de Viviendas de renta limitada, de 15 de julio de 1954 (reproducido casi literalmente en el artículo 29 del Reglamento de 24 de junio de 1955), que establece también, por durante un plazo de veinte años, una reducción equivalente al 90 por 100 del importe de toda contribución, impuesto, arbitrio, derecho o tasa $\mathrm{u}$ otro cualquier gravamen, ya sea del Estado, Diputaciones, Cabildos insulares o Ayuntamientos, incluso aquellos que graven los materiales de construcción o la ejecución misma de las obras, con la única excepción de las contribuciones especiales que los Ayuntamientos pudieran establecer como consecuencia de la realización de obras y servicios de urbanización.

La Ley de 13 de noviembre de 1957 creó con el nombre de viviendas subvencionadas una nueva categoría dentro de las de renta limitada, siendo clasificadas en el segundo grupo de éstas por el Decreto de 5 de marzo de 1959. Las viviendas subvencionadas, extendidas a todo el territorio nacional en virtud del Decreto de 24 de enero de 1958, gozan, como es natural, de los beneficios fiscales propios de las de renta limitada.

La Orden de 28 de febrero de 1962 señala, finalmente, que la licencia municipal de construcción «deberá expedirse con la bonificación del 90 por 100, conforme a lo dispuesto en el artículo 13 de la Ley de 15 de julio de 1954».

Por nuestra parte, sólo hemos de recordar, con relación a esta materia de las viviendas y de acuerdo con las conclusiones sustentadas en el apartado III de este trabajo, que el texto refundido de la Ley de Régimen local de 1955 sólo reconoce la citada bonificación respecto del arbitrio sobre el incremento del

y tasas en virtud de los propios términos del Decreto-ley de 27 de noviembre de 1953 "sólo será aplicable a las casas que se construyan a partir de la publicación del Decreto en el "Boletin Oficial del Estado".

En cuanto a las contribuciones especiales, las sentencias de 30 de septiembre de 1960 y 24 de junio de 1961, han declarado que gozarán de la bonificación del 90 por 100 respecto de las mismas, las casas acogidas a los beneficios de la Ley de 25 de noviembre de 1944 y Decreto-ley de 19 de noviembre de 1948 (viviendas bonificables), otorgados a los edificios afectados en los años 1946, 1948 y 1950, y ello a pesar de reconocer que la Ley de 15 de jullo de 1954, como veremos en seguida, excluy6 a las contribuciones especiales de la repetida bonificación. 
valor de los terrenos en los términos que expresa su artículo 521. Pero existe además el artículo 10, párrafo 7, del Reglamento de Haciendas locales, según el cual, «los derechos y tasas que recaigan sobre licencias para construcciones $u$ obras de viviendas que hubieren obtenido la calificación legal de protegidas o para la clase media, gozarán de una reducción equivalente al 90 por 100 de su importe». Sin embargo, en puridad de términos, este precepto, por su carácter meramente reglamentario y por no haber sido recogido en el nuevo texto refundido de la Ley de Régimen local, de 24 de junio de 1955 , no puede prevalecer contra lo que resulta de los preceptos de ésta.

\section{Exenciones a favor de entidades benéficas.}

Las decisiones jurisprudenciales que conocemos sobre exenciones a entidades benéficas giran en torno al arbitrio sobre el incremento del valor de los terrenos, respecto del cual, desde su introducción por Real Decreto de 13 de marzo de 1919 y a través del Estatuto, del Decreto ordenador de las Haciendas locales y de los sucesivos textos articulados de la Ley de Régimen local, siempre ha estado exenta «cualquier persona o entidad por los terrenos propios afectos de un modo permanente a servicios de Beneficencia o Enseñanza, cuya exención acuerde el Ayuntamiento y conste taxativamente en la respectiva Ordenanza» (artículo 520, d), de la Ley de Régimen local) (21).

(21) En orden a precisar el sentido y alcance de la exención, la sentencia de $\theta$ de noviembre de 1949 recuerda que sla palabra afectos, que utiliza el Estatuto municipal, tiene un claro y preciso sentido juridico en nuestras leyes, y se refiere a las posesiones o a las rentas sujetas a alguna carga u obligacion».

La sentencia de 8 de abril de 1950 declara que «a los efectos de la exención del arbitrio de plus valia, los preceptos citados en el Considerando anterior (art. 426, $d$ ), del Estatuto) no exigen que los blenes tengan otra relación con la Institución benéfica que ser de su propiedad y que sus rentas sean destinadas siempre al sostenimiento de la misma; a diferencla de otras disposiciones legales, entre ellas el núm. 5.9 del artículo 14 del Real Decreto de 29 de diciembre de 1910, vigente a la sazon, que para la exención de la Contribución territorial exigía que los edificios estuvieran destinados a Hospitales, Asllos, etc., conceptos éstos del destino y la afección que, 


\section{Exenciones a favor de Mutualidades.}

El artículo 10 de la Ley de Mutualidades, de 6 de diciembre de 1941, dispone que las Mutualidades o Montepíos comprendidos en la presente Ley, cuyos Estatutos sean aprobados por el Ministerio de Trabajo, estarán exentas, entre otras exacciones

aunque parecidos, son bastante diferentes, pues mientras que el estar destinado a Asilo exige que el establecimiento benéfico esté instalado en el edificio, basta para estimarlo afecto al fin benéfico, con que sus productos o rentas estén destinados a tal fin...».

La sentencia de 15 de octubre de 1952, en un caso de enajenación de bienes por una Fundacíón benéfico-docente, declara que «para denegar la exención referida, no puede oponerse el precepto del núm. 2. del artículo 108 (idéntico al art. 520, párrafo 2, de la Ley de Régimen local), porque los bienes del Patronato, si bien han sido enajenados en virtud de autorización competente, no han dejado antes de ser vendidos de estar afectos al destino que motivó la exención y, por el contrario, el importe de su venta habia de ser invertido en títulos de la Deuda al 4 por 100, y cuando han dejado de estar afectos a dichos fines ha sido al ser adquiridos por la Sociedad «A», de donde se desprende que para la transmisión de que se trata, el vendedor disfruta de la exención del arbitrio, y que se refiere a transmisiones futuras el precepto contenido en dicho número de ser sometidos los terrenos enajenados al gravamen con la excepción que determina».

Insistiendo sobre el sentido del párrafo 2 del repetido precepto, la sentencia de 17 de enero de 1958 declara que «si bien a tenor del mismo los terrenos comprendidos en el apartado $d$ ) que dejasen de estar afectos al uso o destino que motiva su exención y fueran enajenados serán sometidos a gravamen, como si aquella exención no hubiese existido; de ello no se sigue que la exención desaparece, porque al ser enajenados los terrenos se produce la desafección, ya que dichos preceptos, gramatical y lógicamente interpretados, lo que vienen a establecer, a tal propósito, es la siguiente doble condición: $1 .{ }^{\circ}$, que los terrenos hubiesen dejado de estar afectos al expresado uso o destino, y 2.9, que se enajenasen, pues, como cualesquiera otros no sujetos a fines benéficos». En esta sentencia se declara también que el adquirente, aunque se hubiese obligado en la escritura de venta a abonar los gastos motivados por la venta, no está sujeto al arbitrio, por cuanto éste, tratándose de enajenaciones a título oneroso, recae sobre el enajenante, que está exento.

Finalmente, la sentencia de 24 de diciembre de 1958 abunda en la misma doctrina y hace hincapié en que de interpretarse el referido precepto derogatorio de la exención en otro sentido, se haría inoperante el beneficio del artículo $520, d$ ), de la Ley de Régimen local, porque los supuestos que previene no podrian darse en las fundaciones beneficas, que no pueden transmitir bienes estando vigente su adscripción a título gratuito. 
estatales que menciona, de los recargos municipales y provinciales sobre las referidas contribuciones $y$ de las exacciones $y$ arbitrios de las Corporaciones locales que graven los actos, contratos, documentos y patrimonios de las referidas entidades. (22).

Queda, en todo caso, a salvo la exención del arbitrio de plus valía, reconocida a favor de las Mutualidades y Montepíos por el apartado $g$ ) del artículo 520 de la Ley de Régimen local.

\section{Exenciones a favor de Cooperativas y Economatos labo- rales.}

Vienen establecidas en el artículo 5. del Decrếo de 21 de marzo de 1958, regulador de los Economatos laborales, $y$ en el artículo 4.9 del Decreto de 9 de abril de 1954, regulador de las exenciones fiscales a las Cooperativas, cuales preceptos expre-

(22) No cabe duda de que la fórmula de dicho artículo es lo bastante amplia para entender comprendidos en el mismo texto tanto los impuestos o arbitrios como las otras exacciones municipales, es decir, los derechos y tasas y las contribuciones especiales; y asi, el Tribunal Supremo, en sentencia de 22 de septiembre de 1955, establecio que s...ha de puntualizarse que los derechos y tasas municipales, cualquiera que sea la finalidad económica especifica que cubran, son exacciones, tanto por su naturaleza $y$ contenido inconfundible con los precios publicos, como por su catalogación formal como tales exacciones en el artículo 6. del Decreto de Haciendas locales de 25 de enero de 1946 y actualmente en el artículo 434 de la Ley ç? Régimen local»; y que «el acto de apertura de un establecimiento por una entidad dedicada al ejercicio de cualquier finalidad industrial es el más trascendental de orden práctico para la gestión de sus negocios, conjugándose de este modo las dos condiciones que el artículo 10 de la Ley de 6 de diciembre de 1941 exige para declarar exenta de pago de licencia de apertura de las oficinas de la recurrente».

La sentencia de 15 de noviembre de 1956 abundó en la misma (correcta) tesis establecida en el fallo anteriormente referido, en cuanto a que los derechos por licencia de apertura $y$, en general, los derechos y tasas eran verdaderas exacciones municipales $y$, en consecuencia, han de entenderse comprendidos en la exención concedida por el artículo 10 de la Ley de Mutualidades, de 6 de diclembre de 1941, pero, aparte de ello, se adentró en el problema de la subsistencia de este precepto frente a la disposición derogatoria contenida en el artículo 693 de la Ley de Régimen local (de 1950. hoy art. 719 del texto refundido vigenta), solucionándoio en los términos que hemos expuesto en el apartado I de este trabajo. 
san, en lo que atañe a las Haciendas locales, que la exención de ias contribuciones e impuestos estatales llevará cparejada la de los consiguienies recargos provinciales y municipales (23).

La exención de estos recargos no contradice los preceptos de la Ley de Régimen local, toảa vez que ésta, siguiendo e! principio àe que lo accesorio sigue a lo principal, parece dar por sentado que normalmente la exención del impuesto del Estado lleva aparejada la del recargo municipal, ya que cuando no sucede así, como en el caso del recargo sobre el Impuesto del 3 por 100 que grava el producto bruto de las explotaciones mineras, lo dispone expresamente (v. art. 491, párr. 4).

Aparte de estos recargos, los Economatos y Cooperativas no gozan, pues, de ninguna otra exención respecto de las exacciones municipales, las cuales, por otra parte, de venir establecidas en alguna disposición, habrían de entenderse derogadas por el artículo $719, a$ ), de la Ley de Régimen local (24).

\section{Exenciones a favor de las Cajas de Ahorro.}

El artículo 5. del Decreto de 14 de marzo de 1933, que aprobó el Estatuto para las Cajas Generales de Ahorro Popular, dispuso que disfrutarán de exención de los arbitrios provinciales $y$

(23) Como entre las exenciones de impuestos estatales concedidas en dicho artículo 4.9 figura la Contribución industrial y de comercio y la tarifa 3.3 de Utilidades, la exención municipal afecta a los recargos sobre la Contribución industrial y de comercio (art. 485 de la Ley de Régimen local) y «sobre la Contribución de Utilidades, tarifa 3.0» (art. 486 de la misma Ley, hoy, respectivamente, sobre el Impuesto industrial, cuota de licencia fiscal, y sobre los Impuestos que gravan los Rendimientos del trabajo personal, las Rentas de capital y las de Sociedades y Entidades jurídicas). (Véanse Ordenes de 6 de febrero de 1958, por la que se dictaron normas relativas a la repercusión que la Ley de Reforma tributaria de 26 de diciembre de 1957 tiene en las Haciendas de las Corporaciones locales, y de 31 de julio de 1959, sobre estructura de los Presupuestos locales.)

(24) A mayor abundamiento, la Orden del Ministerio de Trabajo de 19 de mayo de 1958, dictada en cumplimiento del Decreto de 21 de marzo del mismo año, dispone en su artículo 23, con referencia a los Economatos laborales, que en el precio de venta de los artículos que suministren se incluirán «los arbitrios municipales y provinciales». 
municipales, respecto de las operaciones anejas a las Cajas Generates de Ahorro; sus anuncios y rótulos y a los bienes y fincas de su pertenencia, afectos al servicio de las mismas o, en su caso, a la parte de los inmuebles que no produzcan renta por ocuparla para sus fines sociales la Institución propietaria (25).

En la actualidad, las Cajas de Ahorros, conforme a la tesis sostenida en el apartado III de este trabajo, sólo han de gozar de las exenciones reconocidas a su favor por la Ley de Régimen local, y que son: respecto del arbitrio sobre el incremento del valor de los terrenos, los de su propiedad en cuanto se hallen afectos al servicio de las mismas (art. 520, $h$ ), y respecto de los arbitrios sobre solares sin edificar y estén o no edificados y sobre riqueza urbana, las fincas de su propiedad que estén exentas de la Contribución territorial (arts. 504, párr. 1; 558, párr. 1, y 590, en relación al art. 5. del Decreto de 14 de marzo de 1933).

\section{Exenciones a favor de la C.A.M.P. S. A.}

En esta materia deben consultarse: artículo 13 del Real Decreto de 28 de junio de 1927, creador del Monopolio; cláusula 5. ${ }^{a}$ del contrato entre el Estado y la Compañía arrendataria, aprobado por Real Decreto de 10 de enero de 1928; Reales Decretos de 11 de agosto de 1928, 30 de enero y 16 de marzo de 1929 (v. también la sentencia del Tribunal Supremo de 18 de £nero de 1946); Real Orden de 16 de noviembre de 1929; Orden

(25) En parecidos términos se pronunciaba el artículo 3. del Real Decreto-ley de 21 de noviembre de 1921, que aprobó la anterior redacción del Estatuto de las Cajas Generales de Ahorro Popular.

Refiriéndose a un caso concreto de contribuciones especiales, el Tribunal Supremo, en sentencia de 6 de marzo de 1946, denegó la exención a un Monte de Piedad y Caja de Ahorros, a pesar de haber invocado el Decreto de 14 de marzo de 1933. En los fundamentos de la sentencia se declara que la contribución especial por aumento determinado de valor no recae sobre las operaciones peculiares de las Cajas Generales de Ahorro, ni sobre rótulos o anuncios, ni sobre los actos, contratos y documentos necesarios para constituirlas ni, propiamente, sobre los edificios en que realizan sus actividades dentro de unos fines ajenos a lucro o beneficio, que es a lo que de modo expreso se refieren los Decretos de 21 de noviembre de 1929 y 14 de marzo de 1933, y la justifican. 
de 14 de febrero de 1933; artículo 1. del Decreto de 19 de septiembre de 1942; artículo 15 de la Ley de 17 de julio de 1947, y artículos 1. y 2. del Decreto de 23 de agosto de 1957.

$\mathrm{Ni}$ el Real Decreto de creación del Monopolio ni el contrato de éste con el Estado establecían una verdadera exención de toda clase de exacciones municipales. Estas se introdujeron, pasando sobre lo dispuesto en el artículo 319 del Estatuto municipal, por la Real Orden de 26 de enero de 1928, respecto de las que gozasen los productos y elementos del Monopolio, y fueron confirmadas por el Decreto de 19 de septiembre de 1942 únicamente respecto de las que recayeren sobre dichos productos.

La Ley de Régimen local no reconoce la existencia de exención alguna a favor de la C. A. M. P. S. A., por lo que es obligado entender que aquellas exenciones quedaron derogadas por el artículo $719, a$ ), y la disposición final $10^{\mathrm{a}}$ de aquélla.

A nuestro juicio, es inoperante, desde un punto de vista puramente jurídico, el intento del Decreto de 23 de agosto de 1957, que no puede prevalecer sobre un texto legal, de querer revitalizar unas exenciones derogadas, máxime cuando, refiriéndolas a toda exacción que recaiga sobre productos, instalaciones y elementos del Monopolio, les da un alcance que no tenían en el Decreto de 1942. Téngase en cuenta que el caso que estudiamos cae fuera del alcance de la disposición transitoria $4 .^{2}$ de la Ley de Régimen local, por ser el contrato en cuestión posterior a la fecha a que dicha disposición transitoria se refiere (26).

(26) La jurisprudencia del Tribunal Supremo, aunque no se ha pronunciado decididamente sobre este punto, parece dar por supuesto que la C. A.M.P.S. A. no goza frente a los Ayuntamientos de una exención tributaria de carácter general, que, por lo demás, ni el mismo Estado disfruta; toda vez que, aparte de la sentencia de 18 de enero de 1946 (ya citada), que declara aplicable la exención establecida en la Real Orden de 26 de enero de 1928, la sentencia de 22 de diciembre de 1955 considera: exenta a la citada Compañía del pago del arbitrio de plus valia, en un caso especial en que obró «por cuenta del Estado», y la de 13 de mayo de 1958 la declaró exenta del arbitrio sobre importación de mercancías del Ayuntamiento de Ceuta, con base en una exención, establecida con carácter general en la Ordenanza, a favor de la importación de máquinas y enseres para la instalación de nuevas industrias. 


\section{Exenciones a favor de la Compañia Telefónica Nacional de España.}

Están establecidas en las bases $4 .^{\mathrm{a}}$ y $7 .^{\mathrm{a}}$, número 5 , del contrato entre el Estado y la Compañía, aprobado por Decreto de 31 de octubre de 1946 (27).

La Ley de Régimen local no reconoce las expresadas exenciones, por lo que, siguiendo la tesis expuesta en el apartado III de este trabajo, entendemos quedan derogadas por el artículo $719, a$ ), de aquélla, y por su disposición transitoria 1. ${ }^{2}$, sin que pueda prevalecer contra tal derogación lo establecido en el contrato sobre que «las exenciones y excepciones de impuestos, arbitrios y tasas, que se establecen en esta base, tendrán plena efectividad y eficacia, aunque no figuren expresamente consignadas en las leyes o disposiciones que regulen su exacción», y que «no podrán aplicarse en contradicción con el mismo las leyes o disposiciones de carácter general o particular dictadas por el Estado o las Corporaciones de carácter público», pues ello implicaría el absurdo de que por una simple disposición administrativa-el Decreto-quedara vinculada la futura actuación legislativa del Estado. Caso distinto era el del primitivo contrato, ya que por ser posterior y del mismo rango que el Estatuto municipal la disposición que lo autorizó, el Real Decreto-ley de 25 de agosto de 1924 pudo ordenar, como lo hizo en su artículo 2.9, la no aplicabilidad del referido Estatuto a lo establecido en el contrato (28).

(27) Esta disposición mantiene inalterados los beneficios fiscales que ya fueron reconocidos a la Compañía Telefónica en el primitivo contrato autorizado por Real Decreto-ley de 25 de agosto de 1924, cuyo artículo 2.? -ello es importante-establecía que no serian de aplicación al citado contrato, entre otras disposiciones de carácter general, el Real Decreto-ley de 8 de marzo de 1924, que aprobo el Estatuto municipal, ni sus Reglamentos; y en las Reales Ordenes de 27 de octubre de 1924 y 28 de octubre de 1925, asi como en el Reglamento aprobado por Real Decreto de 21 de noviembre de 1929.

(28) $Y$ así, la sentencia del Tribunal Supremo de 18 de febrero de 1931 pudo afirmar que "en cuanto a la exención de arbitrios, es tan terminante el Decreto-ley de 25 de agosto de 1924 y establece de una manera 
14. Exenciones a favor de las Empresas de transportes públicos.

Recordemos que la Ley de Régimen local, siguiendo el criterio de sus antecedentes legislativos, no reconoce a las Empresas de transportes públicos otras exenciones que las recogidas en el epígrafe A) de este apartado IV, y que son las siguientes: artículo 439, cor relación a los derechos y tasas; artículo 468 , párrafo $1, d$ ), respecto de las contribuciones especiales por aumento de valor, y artículo 489, párrafo 3 , en cuanto al recargo sobre el Impuesto de consumo de gas y electricidad (29).

tan clara y determinada la exención de toda clase de arbitrios nacionales, provinciales y municipales, o de otras Corporaciones, a favor de la Compañía Telefónica, así como de contribuciones e impuestos, que no hay lugar a duda de que el Ayuntamiento no puede en forma alguna condicionarle ni limitarle; porque, además, el artículo 2.9 de dicho Decreto-ley ordena que no se aplique en contra del mismo el Estatuto municipal y, por tanto, no puede el Ayuntamiento apoyarse en dicho Estatuto en contra de la Compañía amparada por el Decreto-ley que, además, es postorior a aquél». En el mismo sentido se pronunció la sentencia de 29 de noviembre de 1940 , que declaró a la Compañía Telefónica exenta del pago de tasas por ocupacíon del subsuelo, y la de 25 de febrero de 1946 que, al declararla exenta del mismo concepto tributario, señaló que «las normas del contrato... relevan a la Compañía de toda tributación por esos conceptos, según la base séptima del contrato y artículos 86 y 87 de su Reglamento, frente a cuyas prevenciones no pueden invocarse ni prevalecer porque lo impide la base 26 , último párrafo, del mismo contrato, otras de carácter general o particular, que dictan el Estado o las Corporaciones de carácter público».

Tal doctrina del Tribunal Supremo no creemos sea operante en la actualidad. Si antes los Ayuntamientos no podían invocar el Estatuto contra la Compañía Telefónica, porque ésta estaba amparada por un Decreto-ley posterior a aquél (sentencia de 18 de febrero de 1931), ahora son los Ayuntamientos los que están amparados por una Ley formal, la Ley de Régimen local, que es posterior y de superior rango a la disposición administrativa aprobatoria del contrato. $\mathbf{Y}$ si, en virtud de lo establecido en las cláusulas de éste, no pueden invocarse-como dice la sentencia de 25 de febrero de 1946«otras de carácter general o particular que dicte el Estado o las Corporaciones de carácter público», si puede invocarse, no una disposición administrativa, sino una Ley formal posterior al Decreto aprobatorio del contrato.

(29) Consecuente con lo anterior, el Tribunal Supremo, en sentencia de 13 de marzo de 1950, que contempl6 un caso en el que se pretendia la exención de contribuciones especiales a favor de una Compaña de Tranvías, declaró que «por la naturaleza de la imposición, obliga a todos los 
Dentro de las Empresas de transportes públicos, merecen quizá una atención especial la Red Nacional de los Ferrocarriles

beneficiarios de la instalación, obra o servicio ejecutado..., estando de ella sólo exentas las personas que relaciona el artículo 338 (del Estatuto municipal, equivalente al 572 de la Ley de Régimen local), entre las que no está el Estado por edificios no dedicados a la defensa, y menos aún la Compañía de Tranvias Eléctricos, pues esta Empresa, aunque realice un servicio puiblico, tiene carácter privado y se beneficia especial y directamente..., sin que aparezca en el expediente de concesion se le otorgase por el Ayuntamiento de V. exención especial algunas.

En otro supuesto de contribuciones especiales por obras de pavimentación, el Tribunal Supremo, en sentencia de 10 de marzo de 1956 (ya citada en el apartado $I I$ de este trabajo), estableció la distinción entre acto exento y acto no sujeto, y declaró terminantemente que la Compañía de Tranvías a que el fallo se referia no está exenta de tales contribuciones, aunque en aquel caso concreto la Companfa no quedara sujeta al tributo por inexistencia de beneficio especial.

Asimismo, la sentencia de 8 de julio de 1957, abundando en el criterio establecido en la de 13 de marzo de 1950, dice que un Ayuntamiento puede exigir contribuciones especiales por las obras de sustitución del pavimento a una Compaña de Tranvias, cuando existe beneficio especial para la misma.

En cuanto a los derechos y tasas, la sentencia de 26 de febrero de 1958 da por sentado que las Compañias de Tranvias han de pagar los devengados por ocupación del suelo, subsuelo y vuelo en la via pública, pero reduciendo los que en el caso en cuestión se percibian por un Ayuntamiento en forma de participación en los ingresos brutos, a los obtenidos con la explotación de los tranvias, con exclusión de los que se obtuvieran en las líneas de autobuses, toda vez que estos últimos vehiculos estaban sujetos a la extinguida patente nacional de circulación de automóviles en la que se refundían todos los arbitrios, tasas e impuestos municipales y provinciales, con prohibición para los Ayuntamientos, contenida en el artículo $1 .^{\circ}$ del Reglamento del Impuesto de 28 de junio de 1927, de establecer directa o indirectamente en lo sucesivo ningan arbitrio sobre el uso o la tenencia de los automóviles.

Sobre exenciones en materia de derechos y tasas, otra sentencia, la de 6 de diciembre de 1949, habia declarado exenta a una Compañia de Tranvías urbanos del pago de los correspondientes por ocupación del suelo, subsuelo y vuelo de la vía pública, pero, como hemos visto al citar dicha sentencia en el epigrafe B), 1), de este apartado IV, al referirnos a las exenciones paccionadas, su ratio decidendi no empece lo consignado en el fallo de 26 de febrero de 1958, toda vez que se fundamentó en la circunstancia de haberse estipulado la exención como cláusula de la concesión y con anterioridad a la entrada en vigor del Estatuto municipal.

Hay también una sentencia, que lleva fecha de 6 de diciembre de 1948, la cual exime a una Compania de Tranvias del pago del arbitrio sobre solares, mas también en base a considerar la existencia de una exención paccionada, segun hemos tenido ocasion de ver en el epigrafe B), 1), de este apartado IV, al transcribir en lo menester dicha sentencia. 
Españoles (R. E. N. F. E.) y las Sociedades de Ferrocarriles metropolitanos.

En cuanto a la R. E. N. F. E., no creemos goce de exención general ni especial de exacciones municipales, aparte de las reconocidas por la Ley de Régimen local para las Empresas de transportes y concesionarias de servicios públicos. Tampoco le alcanza la exención de derechos y tasas reconocida por el artículo 439 de dicha Ley a favor de los servicios de transportes explotados directamente por el Estado, por cuanto la R. E. N. F. E., según dispone su Ley fundacional, de 24 de enero de 1941, y el artículo 2. de su Reglamento, de 17 de enero de 1947, tiene personalidad jurídica propia y distinta de la del Estado. De otra parte, el artículo 31 de este Reglamento dispone que «será de aplicación a la Red Nacional de los Ferrocarriles Españoles la legislación tributaria general, con las únicas excepciones contenidas en la base 15 de la Ley de 24 de enero de 1941 ». Y esa base 15 sólo declara exentas de toda clase de impuestos las operaciones $\mathrm{y}$ actos motivados por el rescate de líneas férreas y otras operaciones análogas, y las demás exenciones de que goza respecto de tributos estatales (sobre Valores mobiliarios, Derechos reales, Utilidades, etc.) se le han concedido siempre en virtud de disposiciones específicas (30).

(30) Por lo que se refiere a los Metropolitanos, sólo conocemos la sentencia del Tribunal Supremo de 5 de marzo de 1948, que sienta la peregrina teoría de que la Compañ́a Metropolitano de Madrid, concesionaria del Estado para la explotación del ferrocarril del mismo nombre, no está sometida a la jurisdicción del Ayuntamiento en cuanto a la realización de unas obras para la apertura de pozos de ventilación en la vía pública, pues «la Administración general del Estađo conjugaba, con la aceptación de la Ordenanza municipal de obras en este caso, sus intereses con los del Ayuntamiento de Madrid, sin que ello implique sometimiento a dicha jurisdicción municipal, sino simplemente que la Administración admite $y$ hace suyas señalandolas como propias aquellas prevenciones establecidas en las Ordenanzas de obras municipales de Madrid», y significando, además, que «en orden doctrinal reiteradamente se ha pronunciado este Tribunal afirmando (entre otras, en sus sentencias de 4 de marzo de 1912 y 9 de enero de 1926) la prelación de los intereses generales del Estado sobre los regionales, provinciales y locales, y en las de 1 de febrero de 1873, 23 de abril de 1910 y 1 de junio de 1912, que en cuantas cuestiones se susciten con motivo de la efectividad y extinción de las concesiones, se estará para su resolución, en primer lugar, a la carta $u$ orden concesional». 


\section{CONCLUSION}

A través de la exposición; hecỉa en el apartado IV del presente trabajo, de las referencias que la legislación española contiene respecto a exenciones en materia de Hacienda municipal, puede colegirîa que la cuestión está bastante clara con relación a las exenciones paccionadas y a las establecidas a favor de Ia Iglesia, del Estado, de la Ayuda Americana, de las entidades benéficas, de las Cajas de Ahorro, de las Cooperativas y Economatos y de las Empresas de transportes públicos. En todas estas materias, las exenciones, que en unos casos alcanzan mayor amplitud que en otros, están reconocidas expresa o implícitamente en la Ley de Régimen local y su aplicación no ofrece mayor dificultad que la que presenta en general la de todo precepto legal a los casos concretos.

No cabe decir lo mismo de las exenciones que diversas disposiciones propugnan a favor de las industrias de interés nacional, de las viviendas, de las Mutualidades, de la C. A. M. P. S. A. y de la Compañía Telefónica Nacional de España. En tales casos, en los que las exenciones vienen contenidas en disposiciones extrañas a la Ley de Régimen local, y algunas de ellas, por cierto, de rango inferior en la escala jerárquica de las fuentes de Derecho, dicha Ley solamente alude a la exención del arbitrio sobre el incremento del valor de los terrenos a favor de las casas baratas y protegidas y de las Mutualidades y Montepios (arts. 520 y 521), aparte del precepto del artículo 10, párrafo 7, del Reglamento de Haciendas locales, cuyo alcance ya hemos examinado en el apartado anterior. Queda, por tanto, en pie el problema de la subsistencia de diversas exenciones, que entendemos ha ce resolverse de acuerdo con las conclusiones a que hemos llegado en el apartado III de este trabajo.

Interesa, pues, sobremanera que en la próxima versión de la Lev cie Régimen local se tenga en cuenta este problema, con el fin cie fijar con la debida claridad las exenciones en todas estas màerias, en forma que las declaraciones de la Ley de Régimen Ssca: ro cueden en letra muerta y cue, contra su evidente fuerza de obligar, que debe en todo caso respetarse, no se pretenda 
la aplicación y prevalecimiento de normas constituidas a veces por simples disposiciones administrativas.

En todo caso, debemos insistir en que en esta materia de la concesión de exenciones debería procederse con criterio muy estricto, atendiendo, sí, a la finalidad que con la exención se persigue, pero también al interés económico de las Corporaciones locales. A este respecto, no estará de más referirse al artículo 721 de la Ley de Régimen local, que dice: «1. En lo sucesivo, cuando el Estado otorgue exención de derechos y tasas y arbitrios provinciales y municipales a alguna Empresa o Entidad, quedará subrogado en la obligación de abonar a la Corporación local respectiva el importe de los mismos con arreglo a los tipos de gravamen vigentes en la fecha del otorgamiento, salvo disposición legal en contrario.» «2. En el caso de que por el Gobierno se acuerde la desgravación, total o parcial, de arbitrios ya autorizados, municipales o provinciales, se proveerá a la pertinente sustitución por otros de rendimiento y características similares.» Pues bien, no tenemos noticia de que, en base a este precepto, el Estado haya indemnizado convenientemente a las Corporaciones locales por la concesión de exenciones, por ejemplo, a favor de viviendas, y no creemos obste a la aplicación del precepto el que éste aluda, en su párrafo 1, a «exención», y no a «reducción» o «bonificación», porque, como ya hemos indicado, la exención tanto puede ser total como parcial, y con esta última se identifican, sin ninguna diferencia cualitativa, la reducción y la bonificación.

Finalmente, en apoyo del criterio restrictivo que debe imperar en punto a concesión de exenciones, recordaremos que, por lo que se refiere concretamente a las contribuciones especiales, el artículo 65 de la Ley especial de Barcelona y el 10, párrafo 3, de su Reglamento de Hacienda insisten en que «no se reconocerán más exenciones o bonificaciones que las concedidas por los artículos 468 y 472 de la Ley de Régimen local». 